\title{
Efektifitas Produksi Nutrien Tanaman Sorgum dan Jagung Bagian Aerial Dengan Media Tanam Yang Berbeda
}

\author{
F. A. Yudhika, A. Hanifa, E. Handayanta \\ Program Studi Peternakan, Fakultas Pertanian, Universitas Sebelas Maret
}

\begin{abstract}
ABSTRAK
Penelitian ini bertujuan untuk mengetahui pemanfaatan sludge biogas pada media tanam yang berbeda terhadap produksi nutrien tanaman sorgum dan jagung. Penelitian ini dilaksanakan di lahan perkandangan peternakan sapi potong Izzah Sejahtera Farm di Desa Jagoan, Kabupaten Boyolali, sedangkan analisis proximat dilakukan di Laboratorium Ilmu Nutrisi Makanan Ternak, Program Studi Peternakan, Fakultas Pertanian, Universitas Sebelas Maret, Surakarta. Materi yang digunakan adalah lahan tanam yang mengandung sludge biogas, biji sorgum, biji jagung dan air. Desain penelitian yang digunakan adalah rancangan acak lengkap pola faktorial dengan 2 perlakuan. Setiap perlakuan terdiri dari 3 unit percobaan yang masing-masing terdapat 4 kelompok unit tanaman. Perlakuan berupa lahan yang mengandung sludge (P1) dan lahan yang tidak mengandung sludge (P0), serta tanaman sorgum (T1) dan tanaman jagung (T2). Peubah yang diamati yaitu produksi bahan kering $(\mathrm{BK})$, produksi bahan organik (BO), produksi protein kasar (PK) dan produksi total digestible energy (TDN). Data yang diperoleh dianalisis variansi untuk mengetahui adanya perbedaan perlakuan terhadap peubah berdasarkan uji F taraf 5\% dan apabila terdapat perbedaan yang nyata dilanjutkan dengan uji Duncan's Multiple Range Test (DMRT) taraf $5 \%$ serta analisis deskriptif. Hasil analisis variansi dengan perlakuan lahan yang berbeda menunjukan bahwa terjadi perbedaan nyata terhadap produksi bahan kering antar varietas tanaman dan terjadi perbedaan yang sangat nyata terhadap produksi bahan organik, produksi protein kasar dan produksi total digestible energy antar varietas tanaman.
\end{abstract}

Kata kunci : Jagung, Produksi nutrien tanaman, Sludge, Sorgum

\section{Effectiveness of Nutrient Production of Sorghum and Corn Aerial Crops With Different Cropping Media}

\begin{abstract}
This research aims to know the utilization of biogas sludge on different planting media towards the production of sorghum and corn plant nutrient. This research was carried out in izzah beef cattle multifarm in the jagoan village, Boyolali District, while the proximat analysis was performed in the laboratory of Nutrition Food Science, Major In Farm, Faculty Of Agriculture, Sebelas Maret University, Surakarta. The material used is plantation land containing sludge biogas, seed sorghum, maize seeds and water. The research design used was randomized complete design with factorial pattern 2 treatment. Each treatment consisted of 3 units each experiment there are 4 groups of units of plants. Treatment in the form of land containing sludge (P1) and land that does not contain sludge (P0), as well as sorghum plants (T1) and corn plants (T2). The observed variables, namely the production of dry ingredients, protein production, production of organic matter and total production of digestible energy. The data obtained were analyzed for the presence of variansi difference in the treatment of variables based on the F-test level 5\% and if there is a noticeable difference followed by test Duncan's Multiple Range Test (DMRT) levels 5\% as well as the analysis descriptive. Variansi analysis results with different land treatment indicates that there is a real difference between dry ingredients production towards varieties of plants and the very real differences occur towards the production of organic materials, the production of protein crude and total production of digestible energy between varieties of plants.
\end{abstract}

Keywords: Production of nutrient, Sludge biogas, Sorghum, Sorghum seed

\section{PENDAHULUAN}

Limbah peternakan adalah semua buangan dari usaha peternakan yang bersifat padat, cair dan gas. Kotoran sapi merupakan salah satu limbah peternakan yang dapat menimbulkan permasalahan karena dapat menyebabkan pencemaran, diantaranya bau yang tidak sedap yang dapat mengganggu lingkungan masyarakat di sekitar kandang. Di setiap kabupaten di Indonesia rata-rata menghasilkan 56.288.789,9 ton/tahun, sedangkan yang diolah menjadi pupuk organik atau dimasukan ke dalam digester biogas hanya 10\% (Badan Pusat Statistik, 2015), sehingga sebanyak 50.659.910,9 ton/tahun kotoran sapi belum

*Penulis Korespondensi: Yudhika

Alamat: Jl. Ir. Sutami 36 A Kentingan, Surakarta

E-mail: firstiardho@student.un.ac.id dimanfaatkan. Oleh karena itu, dapat dilakukan pengolahan kotoran sapi menjadi energi alternatif (biogas) yang ramah lingkungan. Hal ini sangat menguntungkan, karena mampu memanfaatkan sumber daya alam tanpa merusaknya sehingga siklus ekologi tetap terjaga.

Pengolahan kotoran sapi menjadi biogas menghasilkan gas sebagai renewable energy dan limbah lumpur biogas yang disebut sludge. Sludge bewarna hitam berbentuk cairan seperti lumpur yang telah hilang gasnya yang memiliki kadar pencemar biochemical oxygen demand (BOD) dan chemical oxygen demand (COD) berkurang sampai 90\% dan sudah tidak berbau. Sludge biogas berpotensi untuk digunakan sebagai pupuk organik bagi tanaman, karena telah terjadi fermentasi dan perombakan anaerobik bahan organik oleh bakteri di biodigester 
yang menghasilkan biogas dan asam organik yang mempunyai berat molekul rendah seperti asam laktat, asam butirat dan asam asetat. Peningkatan asam organik akan meningkatkan konsentrasi Nitrogen $(\mathrm{N})$, Fosfor (P) dan kalium (K) (Ayub, 2004). Menurut Suzuki et al. (2001) cit. Oman (2003) bahwa sludge biogas kotoran sapi mengadung 1,8-2,4\% N; 1,0-1,2\% $\mathrm{P} ; 0,6-0,8 \% \mathrm{~K}$ dan $50-75 \%$ bahan organik, juga mengandung berbagai macam unsur yang dibutuhkan oleh tumbuhan seperti Fosfor (P), Magnesium (Mg), Kalsium (Ca), Kalium (K), Tembaga (Cu) dan Zink $(\mathrm{Zn})$. Kandungan unsur hara dalam limbah biogas terbilang lengkap meskipun jumlahnya sedikit.

Di Indonesia masih banyak terdapat lahan-lahan non-produktif atau lahan kosong yang tingkat kesuburannnya rendah dan belum dimanfaatkan secara benar. Tanah di lahan tersebut biasanya berupa tanah kering yang kurang akan unsur hara. Kurangnya serapan air karena tergantung pada curah hujan mengakibatkan adanya variasi kesuburan lahan serta adanya erosi yang menurunkan kesuburan lahan (Adisarwanto dan Widyastuti, 2002). Salah satu cara untuk memperbaiki kualitas dan kesuburan tanah yaitu dengan pemanfaatan pupuk organik maupun anorganik. Pemberian pupuk organik dapat memperbaiki struktur tanah, menaikan bahan serap tanah terhadap air, menaikan kondisi kehidupan di dalam tanah dan sebagai sumber zat makanan bagi tanaman. Sludge biogas merupakan pupuk organik yang dapat memperbaiki kandungan hara di lahan kering.

Ketersediaan hijauan untuk pakan ternak pada musim kemarau sangatlah terbatas. Iklim tropis di Indonesia menjadi salah satu faktor keterbatasan pakan tersebut, sehingga perlu dilakukan penanaman hijauan yang lebih toleran terhadap lingkungan yang kering. Tanaman sorgum (Sorghum bicolor (L.) Moench) dan jagung (Zea mays) bisa dimanfaatkan karena memiliki keunggulan pada daya adaptasinya yang luas, toleran terhadap kekeringan dan tahan terhadap penyakit (Rismunandar, 1989). Menurut House (1985) bahwa lapisan lilin yang menyelubungi batang melindungi tanaman ini di musim kering yang membantu mengurangi laju transpirasi sehingga efektif dalam memanfaatkan air. Kedua tanaman ini tergolong dalam famili Graminae (Poaceae) yaitu tanaman yang termasuk tanaman biji-bijian. Daya adaptasi yang luas dari kedua tanaman tersebut, memungkinkan untuk memanfaatkan lahan kosong berupa lahan-lahan non-produktif yang dapat menjaga kontunitas pakan. Menurut Hartadi et al. (2005) menyatakan tanaman sorgum bagian aerial tanpa pucuk dalam keadaan segar memilik kandungan 28\% BK; 8,9\% ABU; 2,5\% LK; 34,4\% SK; 6,0\% PK dan $48,2 \%$ BETN, sedangkan tanaman jagung memiliki kandungan 31\% BK; 6,1\% ABU; 2,3\% LK; 25,7\% SK; $8,0 \%$ PK dan 57,9\% BETN.
Berdasarkan penjelasan diatas, lahan kering seperti di daerah Kecamatan Sambi, Kabupaten Boyolali dapat dikembangkan dengan memanfaatkan lahan kosong yang mengandung sludge biogas guna memberikan efek positif terhadap pertumbuhan dan produksi nutrien terhadap tanaman sorgum dan jagung bagian aerial.

\section{MATERI DAN METODE}

\section{Tempat dan Waktu Penelitian}

Pemeliharaan tanaman dilakukan di lahan sekitar perkandangan peternakan sapi potong Izzah Sejahtera Farm di Desa Jagoan RT 03 RW 01, Kecamatan Sambi, Kabupaten Boyolali. Uji proximat sampel hijauan dan pengambilan data dilakukan di Laboratorium Ilmu Nutrisi dan Makanan Ternak, Program Studi Peternakan, serta pengujian kimia sampel tanah dilakukan di Laboratorium Kimia dan Kesuburan Tanah, keduanya di Fakultas Pertanian, Universitas Sebelas Maret, Surakarta.

\section{Materi}

Alat yang digunakan untuk persiapan lahan adalah cangkul, gembor, meteran, pacak perlakuan, paranet, tali rafia, pisau, gunting, serta alat uji analisis proximat (vochdoss, penjepit, timbangan analitik, desikator, oven listrik, crusible, tanur, labu destruksi, kompor listrik, lemari asam, buret, erlenmeyer, gelas ukur dan pipet $5 \mathrm{ml}$ ).

Bahan yang digunakan menggunakan biji sorgum, biji jagung, tanah sludge, serta bahan uji analisis proximat (sampel tanaman sorgum, sampel taaman jagung, $\mathrm{NaOH}, \mathrm{H}_{2} \mathrm{SO}_{4}, \mathrm{HCl}$ dan indikator mix).

\section{Desain Penelitian}

Penelitian ini dilakukan secara eksperimental menggunakan Rancangan Acak Lengkap (RAL) pola faktorial $2 \times 2$. Dua faktor perlakuan antara lain faktor jenis tanaman yaitu tanaman sorgum dan jagung $(\mathrm{T})$ dan faktor jenis media tanam yaitu media tanam (lahan) tanpa sludge biogas dan media tanam (lahan) dengan sludge biogas (P), sehingga akan diperoleh 4 kombinasi perlakuan sebagai berikut :

T1P0 : Sorgum yang ditanam di lahan tanpa sludge biogas

T1P1 : Sorgum yang ditanam di lahan dengan sludge biogas

T2P0 : Jagung yang ditanam di lahan tanpa sludge biogas

T2P1 : Jagung yang ditanam di lahan dengan sludge biogas

Keterangan :

P0 : lahan tanpa sludge biogas,

P1 : lahan dengan sludge biogas, 
T1 : tanaman sorgum (Sorghum bicolor (L.) Moench), T2 : tanaman jagung (Zea mays),

Ulangan yang dilakukan setiap perlakuan ada 3 unit percobaan. Setiap unit percobaan masing-masing terdapat 4 kelompok tanaman.

\section{Metode}

Persiapan Lahan. Lahan yang akan ditanami dilakukan pengukuran luas yang akan digunakan dan membuat pagar mengelilingi lahan penelitian dengan cara memasang bambu dan paranet dengan bertujuan untuk membatasi bila ada hewan pengganggu. Lahan membujur dari barat ke timur dengan ukuran $9 \times 5$ meter. Tanah dengan kandungan sludge berada dibagian timur dengan ukuran 3,85 x 5 meter, dan tanah dengan tanpa adanya kandungan sludge berada di sebelah timur dengan ukuran 3,85 x 5 meter. Pembersihan lahan dari sisa tanaman sebelumnya dan gulma dilakukan menggunakan cangkul dan sabit.

Pengambilan Sampel Tanah. Sampel tanah di ambil 100 gram dengan cara acak di setiap media tanah yang berbeda. Terdapat 4 petak tanaman yang digunakan yaitu 2 petak tanah dengan adanya kandungan sludge (P1) dan 2 petak tanah tanpa adanya kandungan sludge (P0). Pengambilan sampel pertama pada 2 titik ditanah tanpa adanya kandungan sludge (P0) dan 2 titik di tanah dengan adanya kandungan sludge (P1). Jarak pengambilan sampel tanah dari satu titik ke titik yang lain minimal berjarak 1 meter. Analisis sampel dilakukan di Laboratorium Kimia dan Kesuburan Tanah, Fakultas Pertanian, Universitas Sebelas Maret. Hasil pengujian analisis kimia tanah ditunjukan pada Tabel 1 .

Persiapan Media Tanam. Persiapan media tanam dibuat 2 petak antar perlakuan dengan ukuran masing-masing petak dengan panjang 3,8 meter dan lebar 1,85 meter, serta jarak antar petak beda varietas 1,2 meter, sedangkan jarak antar beda jenis tanah 50 cm. Lahan dibiarkan dan digemburkan selama 7-10 hari agar terjadi proses dekomposisi secara sempurna. Manfaat dari pengolahan tanah memberikan media tumbuh yang baik, sehingga tanaman dapat tumbuh dan memberikan hasil yang maksimal (Jumin, 1987).

Persiapan Penanaman. Lahan yang sudah ditanami dilubangi untuk lubang tanam dengan kedalaman sekitar $5 \mathrm{~cm}$ dengan cara ditunggal, jarak tanam yang digunakan adalah $70 \times 20 \mathrm{~cm}$, pembuatan lubang menggunakan alat bantu rafia untuk jarak 20 $\mathrm{cm}$ dan meteran dengan jarak $70 \mathrm{~cm}$. Setiap lubang tanam diisi dengan 3 biji.

Penjarangan. Penjarangan tanaman bertujuan untuk membuang tanaman-tanaman yang mati, terserang penyakit agar memberikan ruang pada tanaman yang hidup sehat agar dapat tumbuh dengan optimal.

Pemanenan. Pemanenan tanaman dilakukan pada tanaman berumur 99-112 hari (tanaman aereal). Pemotongan tanaman dilakukan dengan cara memotong tanaman $5 \mathrm{~cm}$ dari permukaan tanah. Penimbangan dilakukan setelah tanaman sudah selesai di potong guna mencari berat segar tanaman.

Pengambilan data. Pengambilan data dilakukan di Laboratorium Ilmu Nutrisi Makanan Ternak dengan melakukan analisis proximat untuk mencari kadar bahan kering (BK), lemak kasar (LK), serat kasar (SK), abu dan protein kasar (PK). Pengambilan data dilakukan selama 2 minggu.

\section{Analisis Data}

Data yang diperoleh dalam penelitian ini dianalisis menggunakan analisis variansi rancangan acak lengkap (RAL) pola faktorial $2 \times 2$ untuk mengetahui adanya pengaruh perlakuan terhadap peubah yang diamati. Apabila terdapat pengaruh perlakuan maka dilanjutkan dengan uji Duncan's Multiple Range Test (DMRT) untuk mengetahui perbedaan antar perlakuan menggunakan aplikasi $\mathrm{R}$ (De micheaux et al., 2013).

Rumus matematika pola faktorial adalah sebagai berikut:

\begin{tabular}{|c|c|}
\hline & $Y_{i j k}=\mu+\alpha_{i}+\beta_{j}+(\alpha \beta)_{i j}+\varepsilon_{i j k}$ \\
\hline \multicolumn{2}{|c|}{ Keterangan: } \\
\hline $\mathrm{Y}_{i j k}$ & : respon tanaman yang diamati \\
\hline$\mu$ & : nilai tengah umum \\
\hline$\alpha_{i}$ & $\begin{array}{l}\text { : pengaruh perlakuan (tanah sludge biogas) } \\
\text { ke- } 1 \text { dari faktor tanaman }\end{array}$ \\
\hline$\beta_{\mathrm{j}}$ & : pengaruh perlakuan (tanah sludge biogas) \\
\hline & $\begin{array}{l}\text { ke-j dari faktor perbedaan } \\
\text { media tanam }\end{array}$ \\
\hline$(\alpha \beta)_{\mathrm{ij}}$ & $\begin{array}{l}\text { : pengaruh interaksi perlakuan dari faktor } \\
\text { tanaman dan media tanam dari } \\
\text { faktor perbedaan media tanam }\end{array}$ \\
\hline$\varepsilon_{\mathrm{ijk}}$ & : galat percobaan \\
\hline
\end{tabular}

Tabel 1. Hasil analisis kimia tanah

\begin{tabular}{clccc}
\hline \hline No & \multicolumn{1}{c}{ Analisis } & Metode & P0 & P1 \\
\hline 1 & pH & - & 6,15 & 6,32 \\
2 & C. Organik (\%) & Walkey \& Black & 2,26 & 2,24 \\
3 & Bahan Organik (\%) & Walkey \& Black & 3,90 & 3,85 \\
4 & N total (\%) & Kjeldhal & 0,40 & 0,48 \\
5 & P (ppm) & Bray II & 11,69 & 14,39 \\
6 & K (me\%) & Penj. Amn Acetat pH 7 & 0,18 & 0,23 \\
\hline
\end{tabular}

Sumber: Laboratorium Kimia dan Kesuburan Tanah, FP, UNS (2015) 


\section{HASIL DAN PEMBAHASAN}

\section{Produksi Bahan Kering}

Rerata produksi BK tanaman sorgum dan jagung bagian aerial hasil penelitian pada lahan yang berbeda ditunjukkan pada Tabel 2.

Pemanfaatan sludge biogas pada media tanam (lahan) tidak memberikan pengaruh yang nyata $(\mathrm{P}>0,05)$ terhadap produksi $\mathrm{BK}$ tanaman sorgum dan jagung bagian aerial (Tabel 2). Hal ini diduga kandungan unsur hara (khususnya kandungan unsur $\mathrm{N}$, $\mathrm{P}$ dan $\mathrm{K}$ ) pada media tanam dengan adanya sludge biogas belum mampu menyuplai hara seseuai kebutuhan tanaman sorgum dan jagung, terutama untuk pembentukan tunas dan jumlah daun. Jumlah tunas dan daun mempengaruhi produksi BK tanaman. Unsur $\mathrm{N}$, $\mathrm{P}$ dan $\mathrm{K}$ dibutuhkan tanaman untuk melakukan proses fotosintesis yang selanjutnya akan berpengaruh pula pada peningkatan bahan kering tanaman. Proses fotosintesis membutuhkan unsur hara dari dalam tanah sebagai bahan pembuatan khlorofil, agar kinerja fotosintesis maksimal perlu adanya bahan yang dibutuhkan oleh tanaman itu sendiri. Unsur yang sangat berpengaruh terhadap pembentukan khlorofil sebagai bahan dasar proses fotosintesis adalah unsur $\mathrm{N}$, serta unsur $\mathrm{P}$ dan $\mathrm{K}$ sebagai penunjang. Menurut Gardner et al. (1991) cit. Rachman et al. (1994) menyatakan bahwa unsur $\mathrm{N}$ berpengaruh terhadap laju pertumbuhan tanaman dalam pembentukan senyawa yang aktif pada metabolisme tanaman seperti enzim asam nukleat, RNA, DNA dan khlorofil, dalam kondisi ini dapat meningkatkan jumlah daun dan ukuran sel serta sebagai hasil akhir dapat meningkatkan pertumbuhan tanaman (jumlah dan panjang tunas).

Rerata produksi BK tanaman sorgum dan jagung adalah 1,689 dan 2,179 ton/ha. Tanaman sorgum dan jagung yang ditanam di media tanam (lahan) yang berbeda memberikan hasil produksi BK yang berbeda nyata $(\mathrm{P}<0,05)$ (Tabel 2$)$. Hal ini dikarenakan tanaman jagung lebih unggul dari tanaman sorgum, dilihat dari morfologi seperti jumlah batang (tunas) dan daun serta panjang daun. Tanaman jagung mempuyai jumlah daun yang berbeda-beda, yaitu antara 8 sampai 48 dengan rata-rata $12-18$ helai daun setiap tanaman (Effendi dan Sulistiati, 1991), sedangkan tanaman sorgum mempunyai jumlah daun antara 7 sampai 40 dengan rata-rata 9-14 helai daun setiap tanaman dan bergantung pada jenis varietasnya (Gardner et al.,
1981 cit. Andriani dan Isnaini, 2013). Daun tanaman jagung lebih panjang dibandingkan dengan tanaman sorgum yaitu mempunyai rata-rata dapat mencapai $150 \mathrm{~cm}$ dan lebarnya antara $5-13 \mathrm{~cm}$ (Effendi dan Sulistiati, 1991), sedangkan tanaman sorgum mempunyai panjang daun dengan rata-rata $100 \mathrm{~cm}$ dan lebar 4-5 cm (Gardner et al., 1981 cit. Andriani dan Isnaini, 2013). Hal diatas menjelaskan bahwa produktivitas tanaman jagung dari segi jumlah daun dan lebar daun lebih baik dibandingkan dengan tanaman sorgum, sehingga produksi BK yang di hasilkan tanaman jagung lebih tinggi dari tanaman sorgum. Hal ini sesuai dengan pernyataan Effendi dan Sulistiati (1991) bahwa setiap hektar tanaman jagung dapat mencapai 3,14 ton bahan kering, sedangkan menurut Soebarinoto dan Hermanto (1996) melaporkan bahwa setiap hektar tanaman sorgum dapat menghasilkan jerami 2,62 ton bahan kering. Tanaman sorgum dan jagung bagian aerial mempunyai kandungan BK yang sama yaitu sekitar 86\% (Hartadi et al., 2005).

Hasil analisis variansi menunjukan bahwa tidak terdapat interaksi antara tanaman sorgum dan jagung dengan media tanam (lahan) sludge biogas terhadap produksi BK (Tabel 2). Hal ini disebabkan sludge biogas yang terkandung dalam media tanam (lahan) mempunyai sifat slow release (lambat terurai) sehingga perlu adanya waktu untuk menguraikan senyawa-senyawa yang ada di media tanam kemudian diserap oleh tanaman. Menurut Winarto (2010) menyatakan bahwa sludge biogas yang dijadikan sebagai pupuk memiliki sifat slow release (lambat terurai), sehingga senyawa yang terkandung memerlukan waktu untuk diuraikan menjadi senyawa yang lebih sederhana agar dapat diserap secara baik oleh tanaman. Hal ini menunjukan bahwa pemanfaatan lahan dengan campuran sludge biogas belum mampu meningkatkan produktivitas tanaman sorgum dan jagung.

\section{Produksi Bahan Organik}

Rerata produksi BO tanaman sorgum dan jagung bagian aerial hasil penelitian pada lahan yang berbeda ditunjukkan pada Tabel 3.

Pemanfaatan sludge pada lahan tidak memberikan pengaruh yang nyata terhadap produksi BO tanaman sorgum dan jagung bagian aerial (Tabel 3). Hal ini diduga keadaan unsur hara di dalam tanah dengan adanya sludge biogas, khususnya C-organik

Tabel 2. Data produksi BK tanaman sorgum dan jagung bagian aerial hasil penelitian pada lahan yang berbeda (ton/ha)

\begin{tabular}{|c|c|c|c|}
\hline \multirow{2}{*}{ Lahan } & \multicolumn{2}{|c|}{ Tanaman } & \multirow{2}{*}{ Rerata } \\
\hline & V1 & $\mathrm{V2}$ & \\
\hline P0 & 1,609 & 2,088 & 1,849 \\
\hline $\mathrm{P} 1$ & 1,787 & 2,270 & 2,099 \\
\hline Rerata & $1,698^{\mathrm{b}}$ & $2,179^{\mathrm{a}}$ & \\
\hline
\end{tabular}

Keterangan : ${ }^{a, b}$ superskrip yang berbeda pada baris yang sama menunjukkan perbedaan yang nyata $(P<0,05)$. 
Tabel 3. Data produksi BO tanaman sorgum dan jagung bagian aerial hasil penelitian pada lahan yang berbeda (ton/ha)

\begin{tabular}{|c|c|c|c|}
\hline \multirow{2}{*}{ Lahan } & \multicolumn{2}{|c|}{ Tanaman } & \multirow[b]{2}{*}{ Rerata } \\
\hline & V1 & $\mathrm{V2}$ & \\
\hline P0 & 1,460 & 1,963 & 1,711 \\
\hline $\mathrm{P} 1$ & 1,626 & 2,142 & 1,884 \\
\hline Rerata & $1,543^{b}$ & $2,052^{\mathrm{a}}$ & \\
\hline
\end{tabular}

Keterangan : ${ }^{a, b}$ superskrip yang berbeda pada baris yang sama menunjukkan perbedaan yang sangat nyata $(\mathrm{P}>0,01)$

tersedia belum mampu menyuplai hara seseuai kebutuhan tanaman sorgum dan jagung. Kadar bahan organik yang dihasilkan oleh tanaman berasal dari kandungan C-organik dari dalam tanah. Keberadaan unsur hara didalam tanah, khususnya karbon (C) sangat dibutuhkan dalam penyerapan sebagai bahan pembentukan bahan organik hijauan, karena sebagian besar bahan kering merupakan bahan organik. Unsur hara karbon yang dibutuhkan oleh tanaman didapatkan dari C-organik media tanam (lahan). Menurut Sutejo dan Kartasapoetra (1990) bahwa C-organik yang ada di dalam tanah diserap oleh tanaman melalui sistem perakaran, kemudian di angkat menuju daun sebagai bahan proses fotosintesis sehingga dapat dihasilkan bahan organik tanaman. Selain selain unsur karbon, unsur nitrogen juga menunjukkan hal yang sejalan dengan produksi bahan kering dan bahan organik hijauan rumput walaupun jumlahnya tidak sebanyak unsur karbon, semakin banyak kandungan nitrogen yang diserap maka akan memberikan peningkatan produksi bahan organik (Yoku, 2010).

Rerata produksi BO tanaman sorgum dan jagung masing-masing adalah 1,543 ton/ha dan 2,052 ton/ha. Tanaman sorgum dan tanaman jagung memberikan hasil produksi $\mathrm{BO}$ yang berbeda sangat nyata $(\mathrm{P}>0,01)$ (Tabel 3). Hal ini disebabkan karena perbedaan kadar BO tanaman jagung lebih tinggi daripada tanaman sorgum, serta hasil produksi BK tanaman jagung yang lebih tinggi dibandingkan tanaman sorgum. Produksi BO didapatkan dari hasil perkalian antara kadar BO yang didapat dengan produksi BK pada penelitian ini. Kadar BO tanaman sorgum dan jagung yang diperoleh dalam penelitian ini adalah $82 \%$ dan $83 \%$. Menurut Hartadi et al. 2005 menyatakan bahwa kandungan BO pada tanaman sorgum dan jagung adalah 77,8\% dan $78,4 \%$, hal ini sesuai karena kadar BO tanaman jagung lebih tinggi dibandigkan dengan tanaman sorgum. Produksi BK yang pada penelitian ini yaitu 1,689 dan 2,179 ton/ha (Tabel 2), didapatkan bahwa produksi BK tanaman jagung lebih tinggi dari tanaman sorgum.
Hal ini menunjukan bahwa produksi BO tanaman jagung lebih tinggi dari tanaman sorgum yang ditanam di media tanam (lahan) yang berbeda.

Hasil analisis variansi menunjukan bahwa tidak terdapat interaksi antara tanaman sorgum dan jagung dengan lahan (tanah) sludge terhadap produksi BO (Tabel 3). Hal ini diduga unsur hara yang ada di media tanam (lahan) yang mengandung sludge biogas memerlukan waktu yang lebih lama untuk dirubah menjadi senyawa yang lebih kompleks yang kemudian digunakan oleh tanaman sorgum dan jagung. Menurut Winarto (2010) bahwa sludge biogas yang diaplikasikan mempunyai sifat slow release (lambat terurai) sehingga perlu waktu untuk memecah unsur hara yang terkandung agar terdekomposisi secara sempurna untuk menghasilkan hara dalam bentuk yang lebih sederhana agar dapat diserap secara maksimal oleh tanaman.

\section{Produksi Protein Kasar}

Rerata produksi PK tanaman sorgum dan jagung bagian aerial hasil penelitian pada lahan yang berbeda ditunjukkan pada Tabel 4.

Pemanfaatan sludge pada lahan tidak memberikan pengaruh yang nyata terhadap produksi PK tanaman sorgum dan jagung (Tabel 4). Hal ini diduga hara di dalam tanah degnan adanya sludge biogas, khususnya kandungan nitrogen belum mampu menyuplai hara seseuai kebutuhan tanaman sorgum dan jagung. Semakin banyak unsur $\mathrm{N}$ yang tersedia pada media tanam semakin banyak pula bahan baku pembentukan protein. Menurut Poerwowidodo (1992) bahwa semua bentuk ion $\mathrm{N}$ yang diserap oleh akar tanaman akan diubah menjadi bentuk $\mathrm{NH}_{2}$. Jaringan akar yang menyerap N-nitrat, senyawa ini segera mereduksinya menjadi amonium dengan melibatkan ensim yang mengandung molibdenum. Ion-ion amonium atau bentuk $\mathrm{N}$-tereduksi lain dan karbohidrat yang disintesis dalam daun, diubah menjadi asamasam amino di dalam bagian tanaman yang mengandung zat hijau daun (klorofil). Asam-asam

Tabel 4. Data produksi PK tanaman sorgum dan jagung bagian aerial hasil penelitian pada lahan yang berbeda (ton/ha)

\begin{tabular}{lccc}
\hline \hline \multirow{2}{*}{ Lahan } & \multicolumn{2}{c}{ Tanaman } & \multirow{2}{*}{ Rerata } \\
\cline { 2 - 4 } & $\mathrm{V} 1$ & $\mathrm{~V} 2$ & 0,102 \\
P0 & 0,056 & 0,147 & 0,113 \\
\hline P1 & 0,063 & 0,162 & \\
\hline Rerata & $0,059^{\mathrm{b}}$ & $0,155^{\mathrm{a}}$ & \\
\hline
\end{tabular}

Keterangan : ${ }^{\mathrm{a}, \mathrm{b}}$ superskrip yang berbeda pada baris yang sama menunjukkan perbedaan yang sangat nyata $(\mathrm{P}>0,01)$ 
protein, karbohidrat, asam nukleat yang diatur dan ditranslokasikan ke seluruh jaringan tanaman oleh $\mathrm{K}$.

Rerata produksi PK sorgum dan jagung masingmasing adalah 0,059 dan 0,155 ton/ha. Tanaman sorgum dan jagung memberikan hasil produksi PK yang berbeda sangat nyata $(\mathrm{P}<0,01)($ Tabel 4). Hal ini disebabkan karena perbedaan kadar PK tanaman jagung lebih tinggi daripada tanaman sorgum, serta hasil produksi BK tanaman jagung yang lebih tinggi dibandingkan tanaman sorgum. Produksi PK didapatkan dari perkalian antara kadar PK yang didapat dengan produksi BK tanaman. Balabanli et al. (2010) menyatakan bahwa produksi PK tanaman pakan sangat tergantung pada produksi BK tanaman dan kadar PK tanaman tersebut. Kadar PK yang didapat dalam penelitian ini adalah 3,5\% untuk tanaman sorgum dan 7,1\% untuk tanaman jagung. Hal ini sesuai dengan menurut Hartadi et al. (2005) bahwa kadar PK tanaman jagung lebih tinggi dari tanaman sorgum yaitu $8,0 \%$ dan $3,8 \%$. Selain itu, produksi BK tanaman jagung juga lebih tinggi dari tanaman sorgum, yaitu 2,179 dan 1,689 ton/ha (Tabel 2). Poerwowidodo pada tahun 1992 menyatakan bahwa setiap jenis tanaman mempunyai kecenderungan khusus untuk menggunakan bentuk ion nitrogen yang dibutuhkannya dan kecenderungan ini dapat berubah oleh faktor lingkungan, namun umumnya tanaman mampu menyerap dan menggungakan nitrat dan amonium.

Hasil analisis variansi menunjukan bahwa tidak terdapat interaksi antara tanaman sorgum dan jagung dengan lahan (tanah) sludge terhadap produksi PK (Tabel 4). Hal ini diduga unsur hara yang ada dari sludge biogas yang telah tercampur di media tanam (lahan) memiliki sifat slow release (lambat terurai). Menurut Anggara (2012) pupuk kandang memiliki sifat slow release (lambat terurai) sehingga proses penyerapan unsur hara oleh tanaman khususnya unsur N, P dan K tidak cukup tersedia. Sludge biogas dalam media tanam (lahan) memerlukan waktu untuk memecah ion-ion yang lebih sederhana sehingga dapat diserap dan digunakan secara baik oleh tanaman sorgum dan jagung.

\section{Produksi Total Digestible Energy}

Rerata produksi TDN tanaman sorgum dan jagung bagian aerial hasil penelitian pada lahan yang berbeda ditunjukkan pada Tabel 5 .

Pemanfaatan sludge pada lahan tidak memberikan pengaruh yang nyata terhadap produksi
TDN tanaman sorgum dan jagung bagian aerial (Tabel 5). Hal ini diduga kandungan unsur nitrogen $(\mathrm{N})$ pada media tanam dengan adanya sludge biogas belum mampu menyuplai hara seseuai kebutuhan tanaman sorgum dan jagung dalam pembentukan protein kasar, serat kasar dan bahan ekstrak tanpa nitrogen. Bahan organik dan anorganik yang diperlukan untuk menunjang pertumbuhan dan perkembangan tanaman didapat dari dalam tanah atau pupuk. Unsur-unsur seperti $\mathrm{N}$, P dan $\mathrm{K}$ dalam tanah yang mengandung sludge biogas kurang berpengaruh pada tanaman sorgum dan jagung. Unsur-unsur tersebut mempunyai fungsi tersendiri untuk pertumbuhan dan perkembangan tanaman. Penyerapan $\mathrm{N}$ misalnya, $\mathrm{N}$ diserap oleh akar tanaman akan digunakan untuk proses metabolisme. Hasil metabolisme $\mathrm{N}$ akan diakumulasikan untuk menaikkan produksi tanaman, kadar protein, dan kadar selulosa (Sutejo dan Kartasapoetra, 1990). Unsur $\mathrm{N}$ berpengaruh terhadap laju pertumbuhan tanaman dalam pembentukan senyawa yang aktif pada metabolisme tanaman seperti klorofil. Klorofil merupakan pigmen utama ada tanaman. Menurut Ai dan Banyo (2011) klorofil memiliki fungsi utama dalam fotosintesis yaitu memanfaatkan energi matahari, memicu fiksasi $\mathrm{CO} 2$ untuk menghasilkan karbohidrat dan menyediakan energi. Gardner et al. (1991) berpendapat bahwa proses fotosintesis dipengaruhi oleh daya kerja peralatan fotosintesis termasuk klorofil. Klorofil mengandung $\mathrm{N}$, dengan demikian semakin banyak $\mathrm{N}$ tersedia maka semakin tinggi pula hasil fotosintesisnya. Sehingga banyaknya unsur N dalam kandungan tanah yang diserap tanaman akan berpengaruh pula terhadap pembentukan serat kasar, protein kasar, lemak kasar serta bahan ekstrak tanpa nitrogen yang merupakan pembentuk TDN.

Rerata kandungan TDN sorgum dan jagung masing-masing adalah 0,649 dan 0,889 ton/ha. Tanaman sorgum dan jagung memberikan hasil produksi TDN yang berbeda sangat nyata $(\mathrm{P}<0,01)$ (Tabel 5). Hal ini disebabkan karena tanaman jagung memiliki kadar TDN lebih tinggi dibanding kadar TDN tanaman sorgum, serta perbedaan produksi BK tanaman jagung lebih tinggi dari tanaman sorgum.

Hartadi et al. (2005) menyatakan bahwa nilai TDN dipengaruhi oleh serat kasar, protein kasar, lemak kasar dan BETN. Kadar TDN dari tananam sorgum dan jagung bagian aerial yaitu $48 \%$ dan $52 \%$. Tanaman jagung memiliki kandungan serat kasar,

Tabel 5. Data Produksi TDN tanaman sorgum dan jagung bagian aerial hasil penelitian pada lahan yang berbeda (ton/ha)

\begin{tabular}{lccc}
\hline \hline \multirow{2}{*}{ Lahan } & \multicolumn{2}{c}{ Tanaman } & \multirow{2}{*}{ Rerata } \\
\cline { 2 - 4 } & V1 & V2 & 0,745 \\
P0 & 0,643 & 0,848 & 0,793 \\
P1 & 0,656 & 0,931 & \\
\hline Rerata & $0,649^{\mathrm{b}}$ & $0,889^{\mathrm{a}}$ & \\
\hline
\end{tabular}

Keterangan : ${ }^{\mathrm{a}, \mathrm{b}}$ superskrip yang berbeda pada baris yang sama menunjukkan perbedaan yang sangat nyata $(\mathrm{P}>0,01)$ 
protein kasar, lemak kasar dan bahan ekstrak tanpa nitrogen lebih besar dibandingkan dengan tanaman sorgum. Selain itu, produksi BK pada penelitian ini juga mempengaruhi produksi BK, karena perhitungan kandungan TDN dengan mengalikan kadar TDN yang didapat dengan produksi BK tanaman sorgum dan jagung. Penyerapan unsur hara khususnya unsur $\mathrm{N}$ sangat berpengaruh terhadap pembentukan serat kasar, protein kasar, lemak kasar dan bahan ekstrak tanpa nitrogen. Hal ini diduga tanaman jagung lebih baik dari tanaman sorgum dalam menyerap dan mengelola unsur $\mathrm{N}$ yang mengakibatkan kualitas tanaman jagung lebih baik daripada tanaman sorgum.

Hasil analisis variansi menunjukan bahwa tidak terdapat interaksi antara tanaman sorgum dan jagung dengan media tanam (lahan) sludge biogas terhadap produksi TDN (Tabel 5). Hal ini diduga unsur hara yang ada dari sludge biogas yang telah tercampur di media tanam (lahan) belum dapat diserap secara baik oleh tanaman sorgum dan jagung karena memiliki sifat slow release (lambat terurai). Prabawati (2012) menyatakan bahwa pupuk organik khususnya pupuk kandang bersifat slow release yaitu memerlukan waktu yang lama untuk menyediakan unsur-unsur seperti N, P dan K yang diperlukan oleh tanaman. Sehingga memerlukan waktu untuk memecah ion-ion yang lebih sederhana agar sludge biogas yang terkandung dapat diserap dan digunakan secara baik oleh tanaman sorgum dan jagung.

\section{KESIMPULAN}

Simpulan yang dapat diambil dari penelitian ini adalah media tanam (lahan) yang mengandung sludge biogas tidak menaikan produksi nutrien yang meliputi produksi BK, produksi BO, produksi PK dan produksi TDN pada tanaman sorgum dan jagung bagian aerial. Tanaman jagung memiliki produksi nutrien lebih tinggi dibandingkan tanaman sorgum. Tidak terdapat interaksi pada media tanam (lahan) yang berbeda terhadap tanaman sorgum maupun tanaman jagung.

\section{DAFTAR PUSTAKA}

Adjie, M.M., K.H. Quesenberry and C.G. Chamblis. 2006. Nitrogen Fixation and Inoculation of Forage Legumes. Agronomy Department. Institute of Food and Agriculture Science. University of Florida. http://edis.ifas.ufl.edu. Diakses 16 Juni 2016.

Adisarwanto, T. dan Y.E. Widyastuti. 2002. Meningkatkan Produksi Jagung di Lahan Kering, Sawah dan Pasang Surut. Penebar Swadaya, Jakarta.

Affandi. 2008. Pemanfaatan Urine Sapi yang Difermentasi sebagai Nutrisi Tanaman. http://affandi21.xanga.com/644038359/pemanfa atan-urine-sapi-yang-difermentasi-sebagainutrisitanaman/. Diakses pada 10 Desember 2015.
AOAC. 1980. Official Methods Of Analysis Of the Associaton Of Official Analytical Chemist. Edisi Ketiga. Benjamin Franklin Station Washington DC 2004.

Ayub, S.P. 2004. Organik Cair: Aplikasi dan Manfaatnya. Agromedia. Jakarta.

Badan Pusat Statistik. 2015. Populasi sapi potong menurut Provinsi 2009-2016 https://www.bps.go.id/linkTableDinamis/view/id /1016. Diakses pada 28 Februari 2017.

Balabanli, C, S. Albayrak and O. Yuksel. 2010. Effects of nitrogen, phosphorus and potassium fertilization on the quality and yield of native rangeland. Turkish Journal of Field Crops 15(2): 164-168.

Barbarick, K.A. 2006. Organic Materials as Nitrogen Fertilizers. Colorado State University. Colorado.

Cooke, K.M., J.K. Bernard and J.W. West. 2008. Performance of dairy cows fed annual ryegrass silage and corn silage with steam-flaked or ground corn. J. Dairy Sci. 91: 2417-2422.

de Micheaux, P.L., R. Drouilhet and B. Liquet. 2013. The R Software : Fundamentals of Programming and Statistical Analysis. Springer, New York.

du Plessis, J. 2008. Sorghum production. Republic of South Africa Department of Agriculture. www.nda.agric.za/publications. Diakses pada 29 Februari 2017.

Effendi, S. dan N. Sulistiati. 1991. Bercocok Tanam Jagung. Yasaguna, Bogor.

Gardner, F.P., R.B. Pearce dan R.L. Mitchell. 2008. Fisiologi Tanaman Budidaya. Terjemahan. Universitas Indonesia Press, Jakarta.

Guadalupe, A.S. 2000. Organic Fertilizer for Flowers, Vegetables and Plants. http://www.upd.edu.ph/serdef/Philippine\%20Flo riculture\%20Industry/Organic\%20Fertilizer.doc. Diakses tanggal 3 Desember 2016.

Hairiah, K. 1999. Dinamika C Dalam Tanah dalam Diklat Kuliah Kesuburan Tanah Program Pascasarjana. Unversitan Brawijaya. Malang.

Hardjowigeno, S. 2003. Ilmu Tanah Ultisol. Edisi Baru. Akademika Pressindo. Jakarta.

Hartadi, H., S. Reksodiprodjo dan A.D. Tillman. 2005. Tabel Komposisi Bahan Makanan Ternak Untuk Indonesia. Gadjah Mada University Press, Yogyakarta.

Hartatik, W. dan L.R. Widowati. 2006. Pupuk Kandang, hal 59-82. dalam R.D. M. Simanungkalit, D.A. Suriadikarta, R. Saraswati, D. Setyorini dan W. Hartatik (Eds). Pupuk Kandang. Pupuk Organik dan Pupuk Hayati (Organic Fertilizer and Biofertilizer). Balai Besar Litbang Sumberdaya Lahan Pertanian Badan Penelitian dan pengembangan pertanian, Bogor.

House, L.R. 1985. A guide to sorghum breeding. Second Edition. International Crops Research Institute for Semi-Arid Tropics (ICRISAT), India. 
Isrun. 2009. Perubahan status N, P, K tanah dan hasil tanaman jagung manis (Zea mays saccharata sturt) akibat pemberian pupuk cair organik pada Entisols. Jurnal Agroland. p. 16: 4.

Jantje, L. 1997. Teknologi Budidaya Sorgum. Departemen Pertanian Balai Informasi pertanian. Irian Jaya.

Jumin, H.B. 1987. Dasar-Dasar Agronomi. Rajawali Pers. Jakarta.

Kartasapoetra, A.G. 1994. Teknologi Penyuluhan Pertanian. Bumi. Aksara. Jakarta.

Lingga, P. 1991. Petunjuk Penggunaan Pupuk. Penebar Swadaya. Jakarta.

Mapegau. 2000. Pengaruh pemupukan $\mathrm{N}$ dan $\mathrm{P}$ terhadap hasil jagung Kultivar Arjuna pada Ultisol Batanghari Jambi. J. Agronomi. 4 (1): 17-18.

Mudjisihono, R dan H.S. Suprapto. 1987. Budidaya dan Pengolahan Sorgum. Edisi Pertama. Penebar Swadaya, Jakarta.

Nurmala, T. 1998. Serelia Sumber Karbohidrat Utama. Rineka Cipta, Jakarta.

Oman. 2003. Kandungan Nitrogen (N) Pupuk Organik Cair dari Hasil Penambahan Urine pada Limbah (Sludge) Keluaran Instalasi Gas Bio dengan Masukan Feces Sapi. Skripsi. Jurusan Ilmu Produksi Ternak. Institut Pertanian Bogor. Bogor.

Pairunan, J.L. Nanere, S.S.R. Samosir, R. Tangkaisari, J.R. Lalopua, B. Ibrahim dan H. Asmadi. 1997. Dasar-Dasar Ilmu Tanah: Cetakan IV. Badan Kerjasama antar Perguruan Tinggi se-Indonesia Timur.

Pandutama, M.H., A. Mudjiharyati, Suyono dan Wustamidin. 2003. Dasar-Dasar Ilmu Tanah. Jurusan Tanah Fakultas Pertanian Universitas Jember. Jember.

Phrimantoro. 1995. Pemanfaatan Pupuk Kandang. Kanisius. Yogyakarta.

Prabawati, K. 2012. Kajian Pemberian Macam Pupuk Kandang terhadap Pertumbuhan dan Hasil Sorgum Manis (Sorghum Bicolor (L.) Moench) Varietas Numbu dan Kawali di Lahan Kering Kabupaten Ngawi. Skripsi. Universitas Sebelas Maret. Surakarta.

Prariesta, D. dan R. Winata. 2009. Peningkatan Kualitas Pupuk Organik Cair Dari Limbah Cair Produksi Biogas. Tugas Akhir Jurusan Teknik Kimia. Institut Teknologi Sepuluh Nopember. Surabaya.

Purbayanti, E.D., D.R. Lukiwati dan R. Trimulatsih. 1995. Dasar-Dasar Ilmu Tanah. Terjemahan dari 56. Fundamentals of Soil Science. Gadjah Mada University Press. Yogyakarta.

Purwanto. 2007. Metodologi Penelitian Kuantitatif. Pustaka Pelajar, Yogyakarta.

Poerwowidodo, M. 1995. Telaah Kesuburan Tanah. Angkasa Bandung. Bandung.

Poespodihardjo, S. (Ed.). 1983. Inventarisasi Limbah Pertanian (Inventory Of Agricultural Wastes).
Direktorat Bina Produksi Peternakan/Fakultas Peternakan. Universitas Gajah Mada. Yogyakarta.

Rachman, A., S.Tirtosaputro dan Mukani. 1994. Respon Tembakau virginia var. Coker 39 dan coker 48 pada pemakaian nitrogen dan kalium pada tanah vertisol bonjonegoro. Pembr. Littri Vol. XXX No. 3-4, Oktober 1993 - Maret 1994. Puslitbangtri Bogor. Hal:84-90.

Rismunandar. 2006. Sorgum tanaman serba guna. Sinar Baru. Bandung.

Rizqiani, N.F., E. Ambarwati dan N.W. Yuwono. 2007. Pengaruh Dosis dan Frekuensi Pemberian Pupuk Organik Cair Terhadap Pertumbuhan dan Hasil Buncis (Phaseolus vulgaris L.) Dataran Rendah. Jurnal Ilmu Tanah dan Lingkungan, Vol 7: 43-53.

Rosmarkam, A. dan N.W. Yuwono, 2002. Ilmu Kesuburan Tanah. Kanisius, Yogyakarta.

Sastrosupadi, A., 2000. Rancangan Percobaan Praktis Bidang Pertanian. Penerbit Kanisus. Yogyakarta.

Soebarinoto dan Hermanto, 1996. Potensi Jerami Sorgum Sebagai Pakan Ternak Ruminansia. Risalah Simposium Prospek Tanaman Sorgum Untuk Pengembangan Agroindustri, 17-18 Januari 1995. Edisi Khusus Balai Penelitian Tanaman Kacang-Kacangan Dan Umbi-Umbian No. 4-1996: 217-221.

Soetrisno, R.D. 2002. Potensi tanaman pakan untuk pengembangan ternak ruminansia. Pidato Pengukuhan Jabatan Guru Besar pada Fakultas Peternakan. Universitas Gajah Mada. Yogyakarta.

Sumarianto, I.P. 2012. Pagan dan Palawija (Seluk Beluk Tanaman Jagung). http://laporanpraktekantok.blogspot.com/2012/0 6/pagan-dan-palawijaseluk-beluk-tanaman.html. Diakses pada 8 Mei 2017.

Sumarsono, 2005. Pertanian Organik: Cetakan Pertama. Badan Penerbit Universitas Diponegoro. Semarang.

Suparman. M. 2002. Teknik komposisi biji jagung pipilan dalam bauah jagung kering giling. Prosiding TemuTeknis Fungsional Non Peneliti. Pusat Penelitian dan Pengembangan Peternakan. P: $218-229$

Suprapto, H.S. dan A.R. Marzuki, 2005. Bertanam Jagung. Penebar Swadaya, Jakarta.

Sutanto, R. 2002. Penerapan Pertanian Organik. Kanisius. Yogyakarta.

Suzuki, K., W. Takeshi and V. Lam, 2001. Consetration and Cristilization Of Phospate, Ammonium and Minerals in the Effluent Biogas Digester in The Mekong Deltha, Vietnam, Jircan and Cantho University. Cantho Vietnam. Japan Agriculture Research Quarter 32:4: 271-276.

Syam, M., Hermanto dan A. Musaddad, 1996. Kinerja penelitian tanaman pangan, prosiding simposium penelitian tanaman pangan III, Buku 4. Pusat 
penelitian dan pengembangan tanaman pangan. Bogor.

Tisdale, S.L. and H.L. Nelson, 1965. Soil Fertility and Fertilizer. Mc Millanco. New York.

Tjitrosoepomo, G. 2000. Morfologi Tumbuhan. Gadjah Mada University Press. Yogyakarta.

Widodo, T.W., N. Ana, A. Asari dan R. Elita. 2009. Pemanfaatan Limbah Industri Pertanian Untuk Energi Biogas. Balai Besar Pengembangan Mekanisasi Pertanian Serpong Badan Litbang Pertanian. Departemen Pertanian Tromol Pos 2 Serpong Tangerang. Banten.
Yoku, O. 2010. Produksi hijauan dan nilai nutrisi wafer rumput sudan (Sorghum sudanense) sebagai pakan ternak ruminansia. Disertasi. Program Pascasajana Universitas Gadjah Mada. Yogyakarta.

Yuwono, N. W. 2010.2 Fosfor. http://nasih.wordpress.com/2010/11/01 /fosfor/. Diakses pada 28 September 2016.

Zubachtirodin, S. 2007. Wilayah Produksi dan Potensi Pengembangan Jagung. Jagung: Teknik Produksi dan Pengembangan: 464-473. Puslitbang Tanaman Pangan, Badan Litbang Pertanian. Bogor. 